ROCZNIKI TEOLOGICZNE

Tom LXVIII, zeszyt $7-2021$

DOI: https://doi.org/10.18290/rt21687-4

HECTOR SCERRI

\title{
THE CHURCH AND ECUMENISM IN THE THOUGHT OF JOHN HENRY NEWMAN
}

\begin{abstract}
A b s tra ct. This article explores the development of Newman's thought on the Church, throughout different phases of his long life. The article focuses, among other themes, on the nature of the Church, the important introduction to his Via Media (1877), the charismatic dimension of the ekklesia, and the respective roles of the pope, the bishops and the laity, in particular what the latter can contribute to the whole People of God. The article also seeks to delve into the question whether one can talk about ecumenism in the writings of the influential nineteenth-century English man of letters and opinion leader. The conclusion offers some final considerations on what Newman underwent during his long and meandering journey with regard to some basic tenets of his ecclesiology.
\end{abstract}

Keywords: John Henry Newman; Church; Via Media; prophetic office; charismatic dimension; hierarchy; ecumenism.

\section{INTRODUCTION}

Despite the passage of time since his death, John Henry Newman's works and thought still remain a source of inspiration. Newman (1801-1890) lived an authentic Christian life. As expected, his beatification in 2010 and his canonisation in 2019, created - if this were ever required - new interest in this great Englishman of the nineteenth century. During his life, he was often considered to be a controversial personality, because his thought was innovative, and because he was often prepared to think out of the box. During his lifetime, Newman was attacked by both Roman Catholics and Anglicans. The latter

Mgr Prof. HeCtor SCERRI - Associate Professor at the Department of Fundamental and Dogmatic Theology at the Faculty of Theology at the University of Malta; Deputy Dean of this Faculty; President of Diocesan Ecumenical Commission, Malta; Consultor to the Pontifical Council for the Promotion of Christian Unity; address for correspondence: Faculty of Theology, University of Malta, Msida MSD 2080, Malta; e-mail: hector.scerri@um.edu.mt. 
considered him as a traitor, while Roman Catholics treated him with suspicion. With regard to these reactions, Newman himself comments in his renowned work Apologia pro vita sua (1864), where he defends his motivations in being received as a member of the Catholic Church. In the Apologia, Newman shows that he is an honest man, devout and humble, as well as a person who took the vicissitudes of life seriously. ${ }^{1}$

The aim of this research article is to offer a reflection on the Church and ecumenism in Newman's thought. Much has often been written about Newman's The Arians of the Fourth Century: Their Doctrine, Temper and Conduct (1833). This explains why this article will explore other avenues instead, rather than repeating the aim of this mentioned work. The trajectory of this article will lead readers to discover Newman's ecclesiology. In doing so, it is hoped that some elements of embrionic ecumenism will be retrieved. The Ecumenical Movement was not yet conceived, let alone born.

\section{THE NATURE OF THE CHURCH}

In an article published in 2011, the then Anglican bishop of Gibraltar-inEurope, the late Geoffrey Rowell (1943-2017) treats various themes which are deemed to be useful in introducing the central research area of this research. ${ }^{2}$ One is to constantly bear in mind that when he was forty-four, Newman left the Church of England (in a "parting of friends," as he stated). In the Apologia his reply to Charles Kingsley - which as Newman himself confesses is "the story of my religious opinions," he takes into account his own theological pilgrimage. This journey has much to do with the identity of the Church of England, a journey encompassing not only personal and particular episodes in his life, but also the context of the Anglican Church and the University of Oxford where he lived. ${ }^{3}$ It is very interesting to read a letter written by one of Newman's greatest friends, Edward Bouverie Pusey (1800-1882) - one of the main leaders of the Oxford Movement - around the end of 1845 to an anonymous Anglican person, when he had heard of Newman's departure from the Church of England. Reading in between the lines of Pusey's letter, we can read into Newman's heart, as well as identify a number of ecumenical strands:

\footnotetext{
${ }^{1}$ Rino Fisichella, "Newman, John Henry," in Dictionary of Fundamental Theology, ed. René Latourelle and Rino Fisichella (New York: Crossroad, 1994), 734.

${ }^{2}$ Geoffrey Rowell, "Newman, the Church of England and the Catholic Church," New Blackfriars 92, no. 1038 (March 2011): 130-43.

${ }^{3}$ Ibid., 131.
} 
Our Church has not known how to employ him.... Here was one marked out as a great instrument of God, fitted through his whole training, of which, through a friendship of twenty-two years, I have seen at least some glimpses, to carry out some great design for the restoration of the Church; and now after he had begun that work among ourselves in his retirement - his work taken out of his hands, and not directly acting upon our Church.... He has gone as a simple act of duty with no view for himself, placing himself entirely in God's hands.... And who knows what in the mysterious purposes of God's good Providence may be the effect of such a person among them? You too have felt that it is what is unholy on both sides which keeps us apart... It is not anything in our Church which keeps them from acknowledging us, but heresy existing more or less within us. As each, by God's grace, grows in holiness, each Church will recognise, more and more, the Presence of God's Holy Spirit in the other; and what now hinders the union of the Western Church will fall off. ${ }^{4}$

Through this excerpt it becomes evident that there existed a number of mature Anglicans who did not shy away from writing as Pusey did. One is probably struck by their deep sincerity in their ecclesiological reflection. Pusey made a purely ecumenical remark when, in the same letter, he affirmed that someone like Newman, formed within the Church of England by the action of the Holy Spirit, was "transplanted" in the Roman Catholic Church. Moreover, Pusey also affirms that both Churches were struggling against a lack of belief which was then spreading fast. Rowell states that the development of theology in Newman, when he was an Anglican, can be considered as a gift to the Church of Rome. ${ }^{5}$

The internationally acclaimed expert, Ian Ker (1942-), the author of about twenty books on Newman, explains that about two years prior to the birth of the Oxford Movement, Newman had denied the idea of an individual Christianity. Every Christian who affirms that he is Christ's witness has to unite himself with others under "under the authority of the general body." In 1833, the year considered by Newman as the birth of the Oxford Movement, he is convinced that he could not separate Christianity from the Church. In fact, in his Parochial and Plain Sermons, Newman affirms that "The Holy Church has been set up from the beginning as a solemn religious fact ... as a picture, a revelation of the next world, as itself the Christian Dispensation." ${ }^{17}$ In this

\footnotetext{
${ }^{4}$ Henry Parry Liddon, Life of Edward Bouverie Pusey, vol. 2, 1836-1846, 2nd ed. (London 1893), 461, quoted in Rowell, "Newman,"131-32.

${ }^{5}$ Rowell, "Newman," 132.

${ }^{6}$ John Henry Newman, Parochial and Plain Sermons, 1:153, quoted in Ian Ker, "The Church as Communion," in The Cambridge Companion to John Henry Newman, ed. Ian Ker and Terrence Merrigan (Cambridge: CUP, 2009), 137.

${ }^{7}$ Newman, Parochial and Plain Sermons, 2:66, quoted in Ker, "The Church as Communion," 137.
} 
early period in his life and thought, Newman rejects the concept of Church he had when he was still an Evangelical, namely that of a real Church, albeit invisible, and instead embraces that of a Church which is a visible body and an earthly institution. ${ }^{8}$ For him, the Church is the kingdom established by Christ, indeed, "a new Kingdom has been established, not merely different from all kingdoms before it, but contrary to them; a paradox in the eyes of man - the visible rule of the invisible Saviour." 9

Newman was convinced that although this visible communion had an institutional and regal aspect, it was nonetheless fundamentally sacramental. He explained that Jesus left a body, and that this body actually does not disintegrate on account of the sacramental bond it contains: "Christ formed a body. He secured that body from dissolution by the bond of a Sacrament. He committed the privileges of His spiritual kingdom and the maintenance of His faith as a legacy of this baptized society." Church has an invisible aspect, as well as a visible aspect. He avers that this visible body has invisible dimensions. He states that the Church does not remain Church if the Holy Spirit were to leave it because "its outward rites and forms are nourished and animated by the living power which dwells within it." 11 He explains that the Holy Spirit lives in the Church as in an "especial dwelling-place" 12 because he came to make us one in him who died and who is living, and in other words forms the Church. For Newman, the Church is "the one mystical body of Christ ... quickened by the Spirit ... giving it life." 13

As Ian Ker himself affirms, Newman remained ever convinced of the knowledge he had of the Church as the communion of all those who had received the Holy Spirit in baptism. This ecclesiological awareness which he had possesses a scriptural and a patristic basis, and is found both in his Anglican years, as well as when he was received into the Catholic Church which then described itself as an institutional pyramid - in other words, the hierarchy was topmost, followed by the clergy and the religious, and at the very bottom of the pyramid and the most numerous, there was the laity. ${ }^{14}$ Something which strikes several scholars is the Introduction to the work which

\footnotetext{
${ }^{8}$ Newman, Parochial and Plain Sermons, 2:391, quoted in ibid.

${ }^{9}$ Newman, Parochial and Plain Sermons, 6:313-314, quoted in ibid.

${ }^{10}$ Newman, Parochial and Plain Sermons, 7:237, quoted in ibid.

${ }^{11}$ Newman, Parochial and Plain Sermons, 3:207, 222, 224; 5:41, quoted in ibid., 138.

${ }^{12}$ Newman, Parochial and Plain Sermons, 3:270, quoted in ibid.

${ }^{13}$ Newman, Parochial and Plain Sermons, 4:170, 171, 174, quoted in ibid.

${ }^{14}$ See Ian Ker, "The Church as Communion," 138.
} 
will be treated in the next section: Newman does not speak about the Church in terms of clergy and lay persons, but as the Body of Christ. ${ }^{15}$

\section{THE INTRODUCTION TO THE VIA MEDIA (1877)}

An obligatory text within the context of this article is the Lectures on the Prophetical Office of the Church (1837), which he wrote when he was an Anglican, and which he published once again as a Catholic, forty years later, with the name Via Media of the Anglican Church (1877).

In this work, he highlights the triple office of Christ as Prophet, Priest and King and applies it to the Body of Christ. In the introduction he wrote to the Catholic edition of his work, Newman makes an emphasis on ecclesiology. Here he continues to discover the commitment to the middle way or via media. He asserts that the three offices are to be kept in balance in relation to each other, and within themselves. Newman scholars, among whom Sidney John Coulson (1919-1993), talk about continuity from the Anglican ecclesiology of Newman in his Lectures on the Prophetical Office of the Church to the ecclesiology which he embraced in the last thirty years of his life. This is encountered in a work by Coulson - the text of a speech which he delivered during the first Newman Symposium, at Oxford, in 1966. Coulson observes that Newman wanted to speak concretely about the Church as the Body of Christ. Newman's aim is to show that the different aspects of the Church, aspects which at face value appear contrary to each other, may be reconciled. Newman's problem, Coulson affirms, is how he defines the separated parts of the Church, without compromising the unity which reigned prior to the separation. ${ }^{16}$ It is interesting to note that in the Via Media, Newman does not commence with the institutional aspect of the Church, but with a sacramental perspective of the Church as the mystical Body and the bride of Christ, the shrine and organ of the Paraclete Spirit. ${ }^{17}$

In the introduction to the 1877 edition of the mentioned work, Newman talks about the four characteristic marks of the Church - one, holy, catholic and apostolic - and clearly affirms:

\footnotetext{
${ }^{15}$ See ibid., 139.

${ }^{16}$ John Coulson, "Newman on the Church - His Final View, its Origin and Influence," in The Rediscovery of Newman: An Oxford Symposium, ed. John Coulson and Arthur Macdonald Allchin (London: Sheed \& Ward, SPCK, 1967), 121-43.

${ }^{17}$ See Ker, "The Church as Communion," 138.
} 
Christianity, then, is at once a philosophy, a political power, and a religious rite: as a religion, it is Holy; as a philosophy, it is Apostolic; as a political power, it is imperial, that is One and Catholic. As a religion, its special centre of action is pastor and flock; as a philosophy, the Schools; as a rule, the Papacy and its Curia. ${ }^{18}$

Coulson comments that Newman chose to express himself upon the proper nature of the Church in the introduction of the version published in 1877 , keeping in mind that the original was written and published when he was an Anglican. In his study, Coulson explains that Newman originally described the Church in light of a perspective which was influenced by the Anglican tradition. Coulson also avers that in the Apologia Newman confesses that he continued to understand "the visible Church" and "the historic nature of revelation" in light of the Anglican bishop and author Joseph Butler (1692-1752), "the doctrine of Tradition" from a certain John Hawkins in a work which probably saw the light of day in 1792, and "the idea of a Church" as independent from the State from Richard Whateley (1787-1863), a scholar, academic, philosopher and theologian, besides being the Anglican bishop of Dublin (Ireland). ${ }^{19}$

In a letter which he wrote on 9 February 1835 to Samuel Rickards (1796-1865), an opponent of the Oxford Movement, Newman describes the good which came out of Tracts for the Times (1833-1841). He compares the effect of the latter with the use of smelling salts when someone faints: "The stimulus we have been able to give to Churchmen [in the Tracts] has been the application of volatile salts to a person fainting, pungent but restorative. High and true principle there is all through the Church, I fully believe." ${ }^{20}$ Coulson proceeds to explain that for Newman the Church participates in the reality which she herself conveys so that we are able to understand it ("partakes of the reality it renders intelligible"). ${ }^{21}$

According to Geoffrey Rowell, Newman distinguishes between the episcopal tradition and the devotional and popular matrix in the Church in the work which has already been referred to, Lectures on the Prophetical Office of the Church. He distinguishes between the episcopal tradition as this appears in

18 John Henry Newman, The Via Media of the Anglican Church illustrated in Lectures, Letters and Tracts written between 1830 and 1841, vol. 1 (London: Basil Montagu Pickering, 1891), xl. See the easily accessible digital version: https://books.google.com.mt/books?id=ct2Xf91LyF4C\&printsec $=$ frontcover\&source $=$ gbs_ge_summary_r\&cad $=0 \# v=$ onepage $\& q \& f=$ false (accessed October 9, 2020). See also the critical edition by H. D. Weidner (Oxford: Clarendon Press, 1990), 25.

${ }^{19}$ Coulson, "Newman on the Church," 125.

${ }^{20}$ John Henry Newman, Letters and Diaries, vol. 5. Liberalism in Oxford, January 1835 to December 1836, ed. Thomas Gornall (Oxford: Clarendon Press, 1981), 26.

${ }^{21}$ Rowell, "Newman," 135. 
the formal professions of the Creed and the conciliar definitions, and, on the other hand, the imaginative and devotional matrix of the faith from which is derived what Newman calls the prophetic tradition in the mind and life of the Church. When he defends the Anglican via media by the return to the Fathers of the Church and not only to the Scriptures, Newman was opposing the individualism and the private judgement of popular Protestantism, as well as opposing the Church of Rome which, he claimed, had added to the faith. In the Lectures on the Prophetical Office of the Church, which he wrote in 1837 - and therefore when he was an Anglican - Newman was urging the Church of England to return to what he believed was its true identity. When the Church of England of his time refused to identify itself with the programme he was proposing, Newman, together with his Tractarian friends began to lose their trust in Anglicanism. ${ }^{22}$ But, at the same time, one should recall that in the Lectures, Newman criticised modern Catholicism which he found to be in contrast with the religion of the "Primitive Church." In fact, he talks about "alleged corruptions in Catholicism," something he had also mentioned in his work Essay on the Development of Christian Doctrine (1845). ${ }^{23}$

The renowned Irish scholar and historian Eamon Duffy (1947-), too, comments about the Lectures on the Prophetical Office of the Church and their republication in 1877, under the title Via Media of the Anglican Church, which Duffy describes as his last major original work. Duffy explains that during the 1860 s and the 1870 s, Newman worked indefatigably on a systematic re-issue of his Anglican works. When, eventually, Newman completed this edition of his works, he showed the essential catholicity of the works he had gestated and given birth to during his Anglican period, although one encounters certain Catholics - such as the fanatical William George Ward (1812-1882) - who treated these works with suspicion. Duffy upholds that the work under investigation constitutes an original ecclesiological exposition which qualifies as an apologetic defence of the Roman Catholic Church, in contrast to Newman's accusations when he was a young Anglican minister, around the year $1840 .{ }^{24}$

The 1877 introduction to the Via Media commences with an objection which was often raised about the Roman Catholic Church of Newman's time. The objection concerned the discordance between the purity of Catholic theology

\footnotetext{
22 Ibid.

${ }^{23}$ Ker, "The Church as Communion," 138.

${ }^{24}$ Eamon Duffy, “'That Was Then, This Is Now': Some Comments on Newman's 1877 Preface to the Via Media and the Modern Church," New Blackfriars 92, no. 1038 (March 2011): 170. See also Eamon Duffy, John Henry Newman. A Very Brief History (London: SPCK, 2019), 67-72.
} 
and the apparent superstition tied to several Catholic devotional practices and the corruption shown by "ecclesiastics in high positions". However, Newman's main target was all those in the Catholic Church who were damaging its credibility in the context of the evangelisation of an unbelieving world. In fact, the book's introduction is none other than a corrective of Ultramontane ecclesiology (i.e. that vision of the Church which made an extra emphasis on Papal authority and Roman centralisation). Duffy explains that this corrective was written by someone within the bosom of the Roman Catholic Church, yet residing in England..$^{25}$ It is an open secret that Newman was not at all happy with the dogma on papal infallibility, pronounced during the First Vatican Council in 1870. Although he accepted this dogma, at the same time he deemed it as unnecessary, and as a useless shackle on the conscience of many. This is how Newman described it: "unsettling the weak in faith, throwing back inquirers, and shocking the Protestant mind." 26 Those who were in favour of the dogma on infallibility affirmed that any conscientious opposition to it was a sign of a spirit of disloyal dissent. For Newman, this climate was the perfect harbinger for a total eclipse of the theological debate. ${ }^{27}$ The introduction of the Via Media therefore depicts that Newman was uncomfortable with the extra emphasis on the centralisation of ecclesiastical authority. ${ }^{28}$

Another interesting aspect which ought to be mentioned is that in the original Anglican text of the work (1837), Newman binds together popular religiosity and prophecy. However, when he wrote the new 1877 introduction, this time as a Catholic, he refrains from saying anything on this aspect. Instead, he binds popular religiosity with the priestly dimension of the Church, because it is related to devotion and worship. He insists that the Church participates in the priestly, prophetic and kingly office of Christ - a theological truth which will be presented, nearly ninety years later, in the documents of the Second Vatican Council. Newman writes:

These offices, which specially belong to Him as Mediator, are commonly considered to be three; He is Prophet, Priest, and King; and after His pattern, and in human measure, Holy Church has a triple office too; not the Prophetical alone and in isolation, as these

\footnotetext{
${ }^{25}$ Duffy, “That Was Then, Then Is Now'," 170.

${ }^{26}$ John Henry Newman, Certain Difficulties felt by Anglicans in Catholic Teaching Considered, vol. 2 (London: Basil Montagu Pickering, 1876), 299.

${ }^{27}$ Duffy, “"That Was Then, Then Is Now'," 171.

${ }^{28}$ Ibid., 175.
} 
Lectures virtually teach, but three offices, which are indivisible, though diverse, viz. teaching, rule, and sacred ministry. ${ }^{29}$

Newman distinguishes between the effects of these offices in the life of the Church: the priestly office leads to worship; the prophetic office leads to teaching; the kingly office leads to the exercise of authority. This explains why the Church is a community of worship, teaching and authority. In his work under consideration, Newman is convinced that the three aspects converge in the one activity carried out in the name of Christ. Nonetheless, he observes a tension between them, and cautions that each of the three aspects can veer into an erroneous direction if it fails to accept the effect of the two others which creates a balance. In fact, Newman underlines that:

Arduous as are the duties involved in these three offices, to discharge one by one, much more arduous are they to administer, when taken in combination. Each of the three has its separate scope and direction: each has its own interests to promote and further; each has to find room for the claims of the other two; and each will find its own line of action influenced and modified by the others, nay, sometimes in a particular case the necessity of the others converted into a rule of duty for itself. ${ }^{30}$

\section{OTHER REFLECTIONS ON NEWMAN'S ECCLESIOLOGY}

As one can conclude, it becomes clear that Newman embraced the same sacramental reflection about the Church as the Body of Christ, both in his Anglican years, as well as after he was received into the Roman Catholic Church. Other important dimensions which remained unchanged within him include the following: the Church as the temple of the Holy Spirit, and the communion which binds all Christ's faithful together through the sacrament of baptism. The same can be said about his firm convictions on the role of the laity. This is clear in his renowned work "On Consulting the Faithful in Matters of Doctrine" (1859). In the latter, Newman reveals that several bishops during the time of the Arian heresy in the fourth century let the faithful Christians down, because while the latter continued to embrace the authentic faith, the bishops - by and large - were overcome by the current of the heretics. ${ }^{31}$ Ian Ker opines that the article "On Consulting the Faithful" was written by

\footnotetext{
${ }^{29}$ John McDade, "Episcopal and Prophetic Traditions in the Church," New Blackfriars 92, no. 1038 (March 2011): 179.

${ }^{30}$ Ibid.

${ }^{31}$ Ker, "The Church as Communion," 139.
} 
Newman in the context of the controversy which arose when Catholic bishops refused to cooperate with the Government commission on primary education, despite the fact that Catholic schools were receiving state aid. Newman affirmed that the Catholic laity should have been consulted about this matter, as it concerned their children's education. Ker states that here Newman was implicitly accepting the separation in the Church between clergy and laity. ${ }^{32}$

In this 1859 work, Newman makes it clear that the outright distinction between clergy and laity was not a defining characteristic of the early Church. He avers that when one spoke about the Church of the first centuries, the term "faithful" was not synonymous with the laity. The faithful are all the baptised, including bishops, priests and religious. However, it is true that Newman, at times, does use the term "faithful" to refer to the laity, as - already affirmed - during the Arian crisis: "the divine tradition committed to the infallible Church was proclaimed and maintained far more by the faithful than by the episcopate," and "the body of the episcopate was unfaithful to its commission, while the body of the laity was faithful to its baptism." The historian Eamon Duffy expresses this when, while quoting Newman in a work edited by Coulson, he states that the divinity of Jesus Christ was "proclaimed, enforced, maintained and (humanly speaking) preserved far more by the 'Ecclesia docta' [that is the Church that was being taught] than by the 'Ecclesia docens' [the teaching Church]. ${ }^{\prime 33}$ But then, practically at the same time, Newman showed that he wanted to defend all those among the clergy who kept the authentic faith of the Church: "there were numbers of clergy who stood by the laity, and acted as their centres and guides." 34 In the same essay, Newman refers to a particular case when there was absolute unanimity among the clergy and the people to remove an Arian bishop. ${ }^{35}$ Ian Ker, in fact, clarifies this point when he states that the distinction was not between clergy and laity, but between bishops and laity. ${ }^{36}$

After his conversion in 1845 , Newman became more aware of the fact that the Catholic Church had become more clericalised. He came to this conclusion in contrast to the position of the laity within the Church of England. This becomes clear when examining the period of failure when he was made rector of the Catholic University in Ireland. He realised that the reason for the difficulties

\footnotetext{
32 Ibid., 140.

${ }^{33}$ Duffy, John Henry Newman, 52.

${ }^{34}$ John Henry Newman, On Consulting the Faithful in Matters of Doctrine, edition prepared by John Coulson (London: Sheed \& Ward, 1961), 75-76. See Ker, “The Church as Communion," 140.

${ }^{35}$ Newman, On Consulting the Faithful, 94.

${ }^{36}$ Ker, "The Church as Communion," 141.
} 
between himself and Archbishop Paul Cullen (1803-1878) of Dublin (bishop from 1852) was Newman's intention to appoint a financial committee composed of lay persons in order to administer the University's finances, which after all came from donations made by the laity. Newman opined that qualified laity could be appointed to most of the chairs in the University. At the same time, it is interesting to mention the cynical comment made by his bishop in Birmingham, who said: "Who are the laity?" Newman's answer is worth pondering upon: "The Church would look foolish without them.",37

It is worth referring, albeit briefly, to Newman's The Arians of the Fourth Century. Published in 1833, this was his first work. When he came to re-publish this book in 1871, he added an appendix which included an excerpt from "On Consulting the Faithful," together with some changes and additions. In one of these additions which he made, Newman criticised the behaviour of bishops. In fact, in the first paragraph of his 1871 note - and this was just one year after the First Vatican Council and the dogma of papal infallibility - he stated: "And again, in speaking of the laity, I speak inclusively of their parishpriests (so to call them), at least in many places; but ... we are obliged to say that the governing body of the Church came short." 38 From this, and from what has been affirmed earlier, Newman - in using the term "faithful" - was also including priests and religious with the laity. In fact, many consider "On Consulting the Faithful" as a biting criticism addressed to bishops. Newman was very clear when he argued that the bishops should have consulted the laity in a matter which concerned them so directly. ${ }^{39}$ His deep theological conviction was that the faith was not the property of the bishops alone, but of all the faithful. Indeed, as seen earlier in this research article, the faith was preserved by the whole People of God.

\section{THE CHARISMATIC DIMENSION OF THE CHURCH}

Newman was aware of the importance of the charismatic dimension of the Church, and stresses that it is a constitutive dimension. In other words, Newman understood perfectly well the complementarity of the bishops and the

\footnotetext{
${ }^{37}$ John Henry Newman, The Letters and Diaries of John Henry Newman, edition prepared by Charles Stephen Dessain et al., vol. 19, Consulting the Laity, January 1859 to June 1861 (Oxford: OUP, 1969), 141. See Ker, "The Church as Communion," 140.

${ }^{38}$ John Henry Newman, The Arians of the Fourth Century, 445, quoted in Ker, "The Church as Communion," 141.

${ }^{39}$ Ker, "The Church as Communion," 141.
} 
theologians (the hierarchical and institutional dimension) on one hand, and the charismatic dimension on the other, and in so doing he was a forerunner of the Second Vatican Council. Newman describes the Church as "the especial dwelling-place" of the Holy Spirit who bestows several gifts (charismata) upon the Church. In his Apologia Pro Vita Sua (1864), Newman narrates how (as a fifteen-year-old) he was fascinated by the texts of the Church Fathers he had read in the books by Joseph Milner (1744-1797), History of the Church of Christ. Newman recognises that in the Church Fathers one encounters a positive convergence of the two dimensions, the hierarchic and the charismatic. While reflecting upon the early Church until the eighth century, Newman refers to the principle of the popularity of the Church, in the literal sense of the word, namely its being a Church of the people (populus). He recalls the Church at the time of St Ambrose of Milan (c. 340-397) and mentions the situation, then, when Ambrose, a catechumen, was chosen to lead that particular Church: tradition says that the prophetic voice of a boy from the crowd was heard: "Ambrose is bishop". ${ }^{40}$ Newman uses the affirmation that the Church "threw itself on the people". ${ }^{41}$

In his Essay on the Development of Christian Doctrine (1878), Newman writes about monasticism and underlines the immense importance of this charismatic movement in the life and history of the Church. In fact, he avers: "Little did the youth Antony foresee, when he set off to fight the evil one in the wilderness, what a sublime and various history he was opening, a history which had its first developments even in his own lifetime." Newman elaborates upon this development and what ensued. With regard to the charisms received by several individuals, such as Antony, Pachomius, Basil, Benedict and others, he explains that these spiritual gifts were not only for the benefit of these persons, but for the whole Church. He elaborates further as to how these beacons, and others in subsequent centuries, constitute the answer of the Holy Spirit to the Church in different times. In order to savour what Newman wrote, the reader is invited to listen to his prophetic voice:

St Benedict had come as if to preserve a principle of civilization, and a refuge for learning, at a time when the old framework of society was falling and new political

\footnotetext{
${ }^{40}$ John Henry Newman, Historical Sketches (London: Longmans, Green and Co., 1908), 1:343, in Ker, "The Church as Communion," 147.

${ }^{41}$ John Henry Newman, The Letters and Diaries of John Henry Newman, edition prepared by Ian Ker and Thomas Gornall, vol. 4, The Oxford Movement, July 1833 to December 1834 (Oxford: OUP, 1980), 14, 18. See Ker, "The Church as Communion," 147.
} 
creations were taking place ... when the young intellect within them began to stir, and a change of another kind discovered itself, then appeared St Francis and St Dominic. ${ }^{42}$

He then proceeds to mention other great figures in the following centuries, such as St Ignatius of Loyola, and explains how there arose a variety of creative forms of the apostolate, such as instruction and missionary activity. Newman adopts plenty of rhetoric when he describes the Church in the first centuries, and asks whether there existed any similarity with the Church of his own time. When he focuses carefully on the various expressions of the Church indeed, he looks at the Church of England and other Churches - Newman concludes that the Church of Rome (that is, the Roman Catholic Church) was that which most closely resembled the early Church:

The present communion of Rome is the nearest approximation in fact to the Church of the Fathers, possibly though some may think it, to be nearer still to that Church on paper ... Did St Athanasius or St Ambrose come suddenly to life, it cannot be doubted what communion he would take to be his own. All surely will agree that these Fathers ... would find themselves more at home with such men as St Bernard or St Ignatius Loyola. ${ }^{43}$

It seems that the choice made of the last two mentioned saints was intentional. St Bernard of Clairvaux (1090-1153) lived in the initial years of the Eastern Schism, whilst St Ignatius of Loyola (1491-1556) founded the Jesuit order at the same time of the Reformation, and therefore, contemporaneously to the great divisions in Western Europe, as from the mid-sixteenth century.

\section{SOME REFLECTIONS ON ECUMENISM. IS THERE ROOM FOR THIS?}

Despite the colourful life and the great variety of experiences undergone by Newman, it might seem presumptuous to speak of ecumenism in the great nineteenth-century Englishman. While affirming that much has been written about Newman's ecclesiology, the same cannot be stated on the ecumenical thought of the great writer. First of all, one has to recall that Newman lived prior to the formal genesis of the Ecumenical Movement in 1910. It is indeed true that Newman came in contact with what Ian Ker calls "the varieties of Christianity." 44 The renowned Irish theologian and Newman scholar, Thomas

\footnotetext{
${ }^{42}$ John Henry Newman, An Essay on the Development of Christian Doctrine, 398-99, quoted in Ker, "The Church as Communion," 149.

${ }^{43}$ Ibid., 97-98, in Ker, 149.

${ }^{44}$ Ian Ker, Newman and the Fullness of Christianity (Edinburgh: T\&T Clark, 1993), 1-9.
} 
J. Norris does indeed speak about the "ecumenical experience" which the convert to Catholicism underwent. It is my firm opinion that, whilst we can safely state that Newman moved from an Evangelical experience to the Church of England, and later to the Roman Catholic Church - and thus he possessed a first hand experience of these different faith communities - it is inappropriate to talk about ecumenism in the precise meaning of the term, as well as the experience of ecumenical dialogue with regard to the nineteenth-century thinker.

Thomas Norris, nonetheless affirms - and in my opinion this is a very insightful remark - that Newman's "ecumenical experience," whatever this meant to Newman, provides a providentially ecumenical slant to his theology of faith, as well as a particularly Catholic tone to it, because his quest is one in the direction of the fullness of faith. ${ }^{45}$ Norris also states that in Newman's theology of faith there is a tangible tension between the devout Catholic and the dedicated ecumenist. Here, it is appropriate to quote Newman directly in what is probably a unique affirmation about the harm caused by Christian division. In fact, he writes: "The absence of visible unity between ... different communions is so great a triumph, and so great an advantage to the enemies of the cross." 46 This is very true. At the same time, we have to reiterate reference to the context in which Newman lived in nineteenth-century Great Britain. Undoubtedly, we cannot speak of ecumenical dialogue then, but rather about the raging controversies that were so common.

It has to be pointed out that during his Anglican period, Newman met the Roman Catholic priest Fr George Spencer (1799-1864) from the noble family associated with the Althorp estates, and later, Princess Diana (Spencer). After having been an Anglican minister, Spencer became a Catholic in 1830, and later a priest. He was a man of great charity, especially with the poor of his time. In 1846, he joined the Passionist Order, and was given the religious name of $\mathrm{Fr}$ Ignatius of St Paul. He was indefatigable in what he saw as the conversion of England. In the context of his cause for beatification and canonisation, he was declared Venerable by Pope Francis on 20 February 2021. It was George Spencer who early in Newman's life, in 1841, encouraged him to pray for Christian unity, and to join the French Catholics who were praying for the same intention. At first, Newman refused to accept this suggestion, because as he

\footnotetext{
${ }^{45}$ John Henry Newman, Essays Critical and Historical, 2:231-33. This is a reference made by Thomas J. Norris, in his article "Faith," in The Cambridge Companion, 73.

${ }^{46}$ John Henry Newman, The Letters and Diaries of John Henry Newman, edition prepared by Charles Dessain and Thomas Gornall, vol. 24, A Grammar of Assent, January 1868 to December 1869 (Oxford: OUP, 1973), 22. See Norris, "Faith," 73.
} 
said, the Anglicans were already praying for unity, once a week. Eventually, he composed a prayer for unity for Anglican use on Good Friday. ${ }^{47}$ It was Newman himself who then encouraged his fellow Anglicans to pray for unity, every Thursday. One can therefore affirm that Newman was a precursor of what would later be called "spiritual ecumenism."

This section of the article is bound to make a direct and full reference to another prayer composed by Newman. This, too, is a Good Friday prayer for Christian unity, written when he had already become a Catholic:

O Lord Jesus Christ, who, when you were about to suffer, you prayed for your disciples to the end of time that they might all be one, as you are in the Father, and the Father in you.

Look down in pity on the manifold divisions among those who profess your Faith and heal the many wounds which the pride of man and the craft of Satan have inflicted on your people.

Break down the walls of separation which divide one party and denomination of Christians from another. Look with compassion on the souls who have been born in one or other of these Communions which not you, but man has made.

Set free the prisoners from these unauthorised forms of worship and bring them all to the one Communion which you set up at the beginning - the one Holy Catholic and Apostolic Church. Teach all men that the See of Peter, the Holy Church of Rome is the foundation, centre and instrument of unity.

Open their hearts to the long-forgotten truth that the Holy Father, the Pope, is your Vicar and representative: and that in obeying him in matters of religion they are obeying you, so that as there is but one company in heaven above, so likewise there may be one Communion, confessing and glorifying your Holy Name here below. ${ }^{48}$

It is absolutely evident that the content of this prayer and its tone are in sharp contrast to the ecumenical style and language used by Roman Catholics since the Second Vatican Council. The language used by Newman reflects the mentality of his time, namely an ecumenism which meant "a return to Rome" (which, after all, was his own experience culminating in the personal milestone of October 1845), as well as that of Churches and communities in error, from

${ }^{47}$ See Juan R. Vélez, “John Henry Newman's Reluctant Prayer for Christian Unity” (January 25, 2012), in the journal First Things, available at https://www.firstthings.com/blogs/firstthoughts/2012/01/ john-henry-newmans-reluctant-prayer-for-christian-unity (accessed October 31, 2020). Also see Juan R. Vélez, "Christian Unity and Cardinal Newman" (January 23, 2014) on this website - https:// www.cardinaljohnhenrynewman.com/christian-unity-and-cardinal-newman (accessed October 31, 2020).

48 John Henry Newman, Meditations and Devotions. See "Newman's Unity Prayer," http://archiveuat.catholicherald.co.uk/article/23rd-january-1976/5/newmans-unity-prayer (accessed March 11, 2021). 
which they were being called to repent. This explains why it is theologically anachronistic to talk about the ecumenical thought of John Henry Newman, or any commitment in this field. Yet, on the other hand, one is not to exclude various aspects in Newman's thought which can be considered as foundational to certain attitudes which are embraced during ecumenical dialogue at all levels. This could be the research area for a doctoral thesis at any prestigious university.

Roderick Strange (1945-) affirms that for some, particularly those who disagree with his thought, Newman is an obstacle to Christian unity. Strange himself states that Newman is rather a bridge. This leads us to state that this is so because Newman provides us with the credentials and qualities which are helpful in the exercise of ecumenical dialogue. This current scholar delineates four aspects why Newman is so important, even in ecumenism. Strange acknowledges the contribution of another Newman scholar, Stephen Dessain (1907-1976) who identifies the following: (a) the way through which he became aware of what is true and precious for Christians, despite their divisions; (b) the realism he shows with regard to the causes which led to divisions among Christians; (c) his sincerity concerning the failings of the Catholic Church; (d) his desire to offer a full and balanced presentation on Christian truth. ${ }^{49}$

\section{CONCLUDING REMARKS}

Newman finds solace that when faced with so many different voices, the Church of Rome and its head gave him true interior peace. He recalls the many examples from the first centuries when the Church Fathers and the first Ecumenical Councils, particularly Chalcedon (451), found true harmony in asking for Rome's discernment, advice and confirmation. In his Essay on the Development of Christian Doctrine, Newman wrote that when faced with so many heresies and, at times, the bishops' negligence, there is

but one Voice for whose decisions people wait with trust, one Name and one See to which they look with hope, and that name Peter, and that see Rome; such a religion is not unlike the Christianity of the fifth and sixth centuries. ${ }^{50}$

\footnotetext{
${ }^{49}$ Charles Stephen Dessain, "Cardinal Newman and Ecumenism," The Clergy Review 1 (1965): 129ff., quoted in Roderick Strange, John Henry Newman: A Mind Alive (London: Darton, Longman \& Todd, 2010), 96.

${ }^{50}$ John Henry Newman, An Essay on the Development of Christian Doctrine, 322, quoted in Avery Dulles, "Authority in the Church," in The Cambridge Companion, 178.
} 
Newman is aware and understands that several doctrines which are specifically Catholic are in continuity with the deposit of the faith. In his letter to Archbishop Nicholas Wiseman (1802-1865), Newman promised that he would obey the Pope, just as he had previously obeyed his bishop when he was a member of the Church of England. ${ }^{51}$ In another work, Discourses to Mixed Congregations (1849), Newman underlines the importance of a living and infallible Magisterium in order to embrace the Christian faith. He explains how essential is the authority of leadership, in contrast to private judgement:

In the Apostles' days the peculiarity of faith was submission to a living authority. If you will not look out for a living authority, and will bargain for private judgment, then say at once that you have not Apostolic faith. ${ }^{52}$

Here, it is necessary to clarify the development in Newman's thought regarding the Papacy in the Roman Catholic Church. Whereas in his first years as a Catholic, Newman talked in a superlative (and, at times, exaggerated) way about the Pope, his thought later matured, in particular, in relation to infallibility. This development is evident in his philosophical novel Loss and Gain (1848) where the hero-character (Charles Reding) affirms these words when describing the Pope:

Catholics calls him Vicar of Christ, Bishop of Bishops, and the like; and I believe, consider that he, in a pre-eminent sense, is the one pastor or ruler of the Church, the source of jurisdiction, the judge of controversies, and the centre of unity, as having the power of the Apostles, and especially of St Peter. ${ }^{53}$

Earlier, in his Essay on Development (1845), Newman avers that the Pope, together with an ecumenical council, cannot err in matters of doctrine, but then is reticent to take a position on papal infallibility. In his Apologia (1865), Newman eloquently defends the infallibility of the Church (as the historian Eamon Duffy reminds us, too) ${ }^{54}$ but he does not commit himself regarding whether the Pope, alone, can oblige all Catholics on a matter of faith. The development of Newman's conviction, even in the context of the First Vatican Council, is well known. He was the theological adviser to Bishop William Ullathorne (1806-1889) of Birmingham during the Council. Ullathorne was

\footnotetext{
${ }^{51}$ Ibid., 178.

52 John Henry Newman, Discourses to Mixed Congregations, 207, quoted in Dulles, "Authority in the Church," 178.

53 John Henry Newman, Loss and Gain, 394, quoted in Dulles, "Authority in the Church," 179.

${ }^{54}$ Duffy, John Henry Newman, 52.
} 
convinced that there was no pressing need to proceed to the definition of papal infallibility. ${ }^{55}$

Newman's convictions regarding the exercise of Church authority undergo an interesting development. When he was an Anglican minister, he acquired a strong sense of office in the Church and tradition, aspects he lacked when he was a young Evangelical. During the period when as an Anglican he was approaching Catholicism, he grew in his conviction that every bishop had the right to speak with authority, while remaining in communion with all the other Catholic bishops. He became ever more aware that the episcopate required a visible head who exercises universal authority in the name of the Lord. Although, as we have seen, Newman had serious reservations on the dogma of papal infallibility, he insisted that the exercise of infallibility was limited to matters of faith and morals. Newman also insists that the hierarchy was duty bound to consult the laity, since the latter could offer their views on a particular subject. He also affirms that doctrinal definitions made by the shepherds of souls require a margin of interpretation, although always with the assistance of the scrutiny offered by theologians. ${ }^{56}$

As this article is brought to its conclusion, I am bound to state that this area of research requires further endeavour, as there is more material and documentation which require unearthing, and a subsequent analysis. Nonetheless, the greatness of John Henry Newman continues to be made more evident, if ever there was any need to affirm this. Although Newman is often the subject of research, academic conferences and books which are quoted and consulted on account of other themes (like his spiritual journey, his homilies as an Anglican, the primacy of conscience, the importance of the laity, the faith), this article bears witness to the importance of his reflections on the Church. There is no doubt that in every phase of his life, Newman showed a great love for the Church, about which he reflected so profoundly, and about which he was so open to express the development of his thought about it.

It is appropriate that the finale of this article should refer to the homily made by Pope Benedict XVI, at Birmingham, when he beatified Newman, on 19 September 2010:

While it is John Henry Newman's intellectual legacy that has understandably received most attention in the vast literature devoted to his life and work, I prefer on this occasion to conclude with a brief reflection on his life as a priest, a pastor of souls. The warmth and

\footnotetext{
${ }^{55}$ Dulles, "Authority in the Church," 179.

${ }^{56}$ Ibid., 185.
} 
humanity underlying his appreciation of the pastoral ministry is beautifully expressed in another of his famous sermons: "Had Angels been your priests, my brethren, they could not have condoled with you, sympathized with you, have had compassion on you, felt tenderly for you, and made allowances for you, as we can; they could not have been your patterns and guides, and have led you on from your old selves into a new life, as they can who come from the midst of you" ("Men, not Angels: the Priests of the Gospel," Discourses to Mixed Congregations, 3). He lived out that profoundly human vision of priestly ministry in his devoted care for the people of Birmingham during the years that he spent at the Oratory he founded, visiting the sick and the poor, comforting the bereaved, caring for those in prison. ${ }^{57}$

This is, in my opinion, the greatest legacy of a holy man who struggled interiorly, reflected, prayed, debated, wrote, loved the Church and offered his life to it. This is one of the reasons why Newman's testimony remains very relevant to Christians of the twenty-first century.

\section{BIBLIOGRAPHY}

Duffy, Eamon. “'That Was Then, This Is Now': Some Comments on Newman's 1877 Preface to the Via Media and the Modern Church.” New Blackfriars 92, no. 1038 (March 2011): 170-75.

Duffy, Eamon. John Henry Newman: A Very Brief History. London: SPCK, 2019.

Fisichella, Rino. "Newman, John Henry." In Dictionary of Fundamental Theology, edited by René Latourelle and Rino Fisichella, 734-38. New York: Crossroad, 1994.

Ker, Ian T., and Terrence Merrigan, eds. The Cambridge Companion to John Henry Newman. Cambridge: Cambridge University Press, 2009.

McDade, John, "Episcopal and Prophetic Traditions in the Church." New Blackfriars 92, no. 1038 (March 2011): 176-88.

Merola, Giuseppe, ed. Il cuore parla al cuore: John Henry Newman e i Papi. Vatican City: Libreria Editrice Vaticana, 2019.

Newman, John Henry. Parochial and Plain Sermons. 8 vols. London: Rivington, 1868.

Rowell, Geoffrey. "Newman, the Church of England and the Catholic Church." New Blackfriars 92, no. 1038 (March 2011): 130-43.

Strange, Roderick. John Henry Newman. A Mind Alive. London: Darton, Longman \& Todd, 2010.

${ }^{57}$ Pope Benedict XVI, "Homily at the Beatification of Cardinal John Henry Newman, Cofton Park, Rednal, Birmingham, September 19, 2010," in Insegnamenti di Benedetto XVI, vol. 6/2 (Vatican City: LEV, 2011), 266. 


\section{KOŚCIÓŁ I EKUMENIZM W MYŚLI JOHNA HENRY’EGO NEWMANA}

\section{Streszczenie}

W artykule analizowana jest ewolucja myśli Newmana na temat Kościoła na różnych etapach jego długiego życia. Autor skupia się m.in. na naturze samego Kościoła, wprowadzeniu, które Newman napisał do swojego dzieła Via Media (1877), charyzmatycznym wymiarze eklezji, roli, jaką odegrali poszczególni papieże, biskupi i świeccy, a w szczególności na roli tych ostatnich w życiu całego Ludu Bożego. Przeanalizowano także kwestię, czy w pisarstwie tego wpływowego Anglika i przywódcy intelektualnego z XIX wieku odnajdziemy wątki ekumeniczne. W konkluzji autor przedstawia swoje refleksje dotyczące długiej i krętej drogi, jaką podążał Newman, formułując podstawowe założenia swojej eklezjologii.

Słowa kluczowe: John Henry Newman; Kościół; Via Media; powołanie prorockie; wymiar charyzmatyczny; hierarchia; ekumenizm. 